\title{
Female-Headed Households and Living Conditions in Latin America
}

Chia Liu, Albert Esteve, Rocío Treviño

\section{Introduction}

The number of households headed by women in Latin American has increased dramatically over the last four decades. Historically, these households consisted of lone women raising children without the support of their absent fathers due to high instability of unions, (De Vos, 1987; Lavrin, 1989; Osborne, Manning \& Smock, 2007; Villarreal \& Shin, 2008) and, as a result, were associated with the feminization of poverty (Arias \& Palloni, 1999; Buvinic \& Gupta, 1997; Chant 2007; Gimenez, 1999; Kimenyi \& Mbaku, 1995; Marcoux, 1998; Pearce, 1978). In this paper we investigate, first, how family changes - including the rise in cohabitation, divorce and separation, non-marital childbearing, and lone motherhood-have affected recent trends in female headship and, second, whether the living conditions of female-headed households differ significantly from those of male-headed households, and the family circumstances in which female-headed households are more likely to experience worse or better living conditions than male-headed households.

Recent research has theoretically and empirically challenged the linkage between female headship and poverty as well as widening public debate on the subject by questioning both the concept of "feminization" (Chant, 2003; Medeiros \& Costa, 2008) and measurement of poverty (Chant, 2003, 2007; Medeiros \& Costa, 2008; Moser, 2010; Quisumbing, Haddad \& Peña, 2001). We aim to contribute to the literature by examining differences in material living conditions between male- and female-headed households. We have taken a large-scale, quantitative perspective and used census microdata samples from 14 Latin American countries, focusing on the family circumstances of the household head.

[Figure 1 here]

Figure 1. Percentage of women aged from 35 to 44 heading households from 1970 to 2010 
The paper is organized into four sections. First, we provide a summary overview of salient characteristics of Latin American family systems and general changes over the last four decades in order to provide a basis for our account of the relationship between female-headed households and the feminization of poverty in Latin America. Second, we present the data and methodology and, in particular, our measurement of living conditions. Third, we show the results divided into two subsections: i) trends in female headship and changes in the union and motherhood status of women, and ii) the results of logistic regression models in which we examine the link between poor living conditions and female headship. We conclude the paper with a discussion of our findings.

\section{Background}

\section{Female headship and changing patterns in union formation}

The presence of female-headed households is an increasingly significant feature of Latin American family systems (Chant, 2003; De Vos, 1987; Lavrin, 1989; Moser, 1993; Villarreal \& Shin, 2008). In colonial societies, female headship appeared as a result of the gender power imbalance between male colonizers and female members of indigenous populations. The social norms prohibiting interracial and interethnic marriage and the existence of cohabiting and "visiting unions" contributed to the high levels of female headship (García \& Rojas, 2002; Socolow, 2000). These levels varied from country to country due to socio-ethnic diversity and the processes of acculturation in each case. Historically speaking, female headship was predominantly a Caribbean and Central American phenomenon (Massiah, 1983; Robichaux, 2013) and was far less prevalent in countries with large inflows of European migration (Argentina, Chile and Uruguay) and in those where the Catholic marriage was more strongly institutionalized (Quilodrán, 1999).

Several researchers have suggested that the instability of unions, especially in the form of cohabitation, is one of the main historical causes for female headship in Latin America. Marriage and cohabitation have long coexisted in the history of Latin America (Castro, 2002, De Vos, 1995; Stromquist 1998). Cohabitation was regarded as the "marriage" of the most disadvantaged social groups, whereas marriage was prevalent among the social elite (Castro, 2002; Socolow, 2000; 
Stromquist, 1998). Latin American societies have witnessed a dramatic expansion of cohabitation and rapid deinstitutionalization of marriage over the last three decades. Cohabitation has become the norm among young women in unions in such countries as Colombia, Brazil, Uruguay and Argentina, and has extended into all layers of society, including the most educated populations (Esteve, GarcíaRomán \& Lesthaeghe, 2012). Together with the expansion of cohabitation, the percentage of children born out of wedlock and the number of single mothers have increased in the three decades from 1970 to 2000 (Esteve et al., 2012; Laplante et al., 2015). Some authors have connected the overall family changes described here to the onset of the Second Demographic Transition in Latin America (CovreSussai, Meuleman, Botterman, \& Matthijs, 2015; Esteve et al, 2012; Lesthaeghe, 2014), which may have implications for changes in the context and nature of female headship, as we shall discuss in this paper.

Bearing in mind the above, and given the historical link between female headship, cohabitation and union instability in Latin America, we raise the question of whether there is a positive relationship between the rise in female headship and recent demographic changes with regard to union formation and dissolution, namely the rise in cohabitation, divorce and separation, non-marital childbearing, and lone motherhood. If cohabitating women are more likely to have children at young ages and more likely to abandon their unions than married women, the cohabitation boom may have laid the foundations for the increase of female headship.

It is important to note that not all female household heads in Latin America are single mothers in unstable unions, and neither do all single mothers necessarily become the household head. Research has shown that extended households provide shelter to lone mothers. The percentage of young single mothers living in extended households in the early 2000s ranged from 56.8 per cent in Bolivia in 2001 to 81.8 per cent in Chile in 2002 (Esteve et al., 2012), signalling that female headship is not exclusively the result of union instability. It may have transpired from other life events. For example, widowhood is one of the most important causes of female headship among older women. Since we are specifically interested in the effects on female headship of union formation, instability, 
and dissolution, we have limited the analysis to adult women aged between 35 and 44. At these ages, the percentage of female widows is small, typically below 5 per cent.

Female headship can also be the consequence of separation between wife and husband due to internal or international migration. This situation yielded a non-negligible number of married women heading their households in the absence of the spouse, a category which we identify as married spouse absent. In Mexico, for instance, the male-dominated migration to the United States has a direct impact on household structures in the sending communities, as seen by the large presence of married women with the spouse absent. Fortunately, our data allows us to distinguish between married women with and without an absent spouse and to test the importance of this category for the recent increase in female headship. The importance of remittances, family structure and ties between migrants and relatives living in their countries of origin will have direct consequences on the living conditions of such households (Sana \& Massey, 2005).

Selective female internal migration from rural to urban zones in Latin America has also contributed to the increase of female headship in the region (Chant, 2015). Female headship is higher in urban areas due to women's access to independent housing and higher salaries compared to rural areas, where it even happens that women workers are often unpaid (ECLAC, 2014, p.179). Moreover, women in urban areas may be less exposed to patriarchal control and live more anonymous lives, which allows them to manage their living arrangements with greater autonomy, although segmentation by sex in the informal economy and access to different urban spaces continue to complicate the relationship between urban prosperity and gender (Chant, 2013). Our analysis therefore accounts for the urban-rural dimension of household headship.

To this point, the discussion pertaining to female headship mostly revolves around women who have lived in union but whose male partners are no longer in the household either due to death, migration or separation. Although this situation accounts for the majority of cases, we cannot ignore the fact that a growing number of partnered women may report that they head the household even in the presence of their male partner and that, increasingly, women who have never lived in union also 
head households. From the standpoint of female empowerment, women who are unsatisfied with their relationship may have actively sought household headship as a means of taking control over their lives (Chant, 2008; Chant, 2015). The presence of such trends might be a powerful indicator of a more equal gender outlook on family headship.

In this regard, recent family changes in Latin America, such as the delay of union formation, childbearing, the decline of marriage and the rise of solo living echo the demographic experience of western nations in the past few decades. These phenomena have been connected to the arrival of the Second Demographic Transition in Latin America, driven to a large extent by the process of female emancipation (Lesthaeghe, 2014). The increase of female headship may be seen as a trend that is interdependent with shifts in demographic changes and related with the propensity of a woman to marry, have children, divorce, or stay single. Hence the likelihood of a woman being the head of her household and the relationship of this with poverty cannot be discussed without further investigation into her relationship status.

\section{Female headship and living conditions}

The literature on poverty in Latin America, particularly earlier work, stressed the relationship between female-headed households and the feminisation of poverty (Buvinic \& Gupta, 1997; Pearce, 1978). The paradigm of the feminisation of poverty took hold in Latin America during the so-called "lost decade" following the financial crisis of the 1980s and 1990s. This decade, marked by significant social and economic downturns in the region, resulted in declining wages and lower female labour force participation which was a significant factor in heightened familial instability and a surge in internal and external male migration (Loza Torres, Vizcarra Bordi, Lutz Bachère, \& Quintanar Guadarrama, 2007; Sana \& Massey, 2005). At that time, women had three main disadvantages compared to men: less education and fewer entitlements; lower return for a heavier work load; and

more obstacles in socioeconomic mobility (Moghadam, 2005). Additionally, intergenerational transmission of poverty is of particular concern to researchers and policy makers (Alvarado Merino \& 
Lara; Chant, 2008). Bearing in mind the above, female-headed households became a focal point for social intervention and research, but lack of precision and a paucity of empirical evidence in statements supporting the feminization of poverty gave rise to fervent debate (Alvarado Merino \& Lara, 2016). Recent works have not only questioned the connection between female headship, household poverty, and social vulnerability (Chant, 2003; Damián, 2003; Klasen, Lechtenfeld, \& Povel, 2015) but have also provided a new perspective on the interpretation of female headship, which is seen as an indication of female empowerment rather than vulnerability (Arriagada, 2006; Datta \& Mcllwaine 2000; Chant, 2015).

The critics of feminisation of poverty have based their arguments on three main factors (Chant, 2015). First, female-headed households are not necessarily worse off than male-headed households. Second, poverty is a multidimensional concept which should not be confined to any one dimension such as income or expenditure costs. Third, the poverty gap between female- and maleheaded households does not necessarily increase over time. Study of female-headed households must accordingly: (i) account for the multidimensional and dynamic nature of poverty, including the dimensions of power, agency, and vulnerability; (ii) investigate the heterogeneity of family contexts in which women head their households (Finley, 2007; Fuwa, 2000); and (iii) capture the heterogeneity of female-headed households (Chant, 2015).

To date, there are not many large, representative cross-national empirical studies on this topic based on dimensions of poverty other than income (Chant, 2005; Chant, 2015). Moreover, the measurement of poverty based on household income, consumption or expenditure using crosssectional data has been criticized as being overly dependent on the particular circumstances of the family at the time of the survey (Moser \& Felton, 2009). In societies largely reliant on the subsistence economy, the asset accumulation approach has proved to be more efficient than income or consumption when calibrating long-term household welfare (Carter \& Barrett, 2006; Hohmann \& Garenne, 2009) and a more reliable proxy for inequality measurement (McKenzie, 2004). The assets approach in poverty analysis has an additional advantage as it serves to overcome the stochastic shock of income (Moser \& Felton, 2009). The asset accumulation approach is widely used by institutions 
such as the World Bank and many researchers (Arias \& De Vos, 1996; Booysen, van der Berg, Burger, Maltitz, \& Rand, 2008; Chant, 2015; Deere, Alvarado, \& Twyman, 2012; Harttgen \& Klasen, 2012; Moser \& Felton, 2009; Moser, 2010; Permanyer, 2013).

\section{Data and Methodology}

This study utilises harmonised census microdata published through the Integrated Public-Use Microdata Series International (IPUMS-i), which facilitates reliable cross-national comparisons (Minnesota Population Center, 2015). IPUMS-i holds the largest collection of individual census microdata samples from Latin America, both in terms of the number of countries included and the time span, which runs from 1960 to 2010. In our study we analyse 14 countries: Argentina, Brazil, Chile, Colombia, Costa Rica, Ecuador, El Salvador, Mexico, Nicaragua, Panama, Paraguay, Peru, Uruguay, and Venezuela. For each country, we have several census samples from different points in time. Our final analysis is based on a total of 50 data samples spanning the years from 1970 to 2011 , chosen in accordance with the availability of comparable indicators. Given the cross-sectional nature of the data, we do not intend to establish causality with our study.

To decompose trends in female headship by union status, we focus on females aged from 35 to 44 and living in private dwellings. Individuals living in institutional group housing are excluded from the analysis. Restricting the study to women aged from 35 to 44 has several advantages. At these ages, most women and men have already been in union and had children. They have also had enough time to experience divorce and separation, while the incidence of co-residence with their children remains high. Widowhood is relatively low compared to older ages. Moreover, working with a tenyear age span with census data (often collected once per decade) circumvents the problem of cohort overlapping in two censuses.

The risk of our results being biased by changes over time in the percentage of 35 to 44 -yearold women who have lived in union is negligible because age at first union and age at first childbearing have remained reasonably constant in Latin America over the past few decades (Esteve, López-Ruiz, \& Spijker, 2013; Fussell \& Palloni, 2004; Heaton, Forste, \& Otterstrom, 2002; 
Rodríguez Vignoli, 2009). Male-headed households are included in the second part of the analysis in order to compare their living conditions to those of female-headed households. As with women, we focus on men aged from 35 to 44 . Although the characteristics of the household head are used as independent variables, the outcome variable of living in poor conditions is constructed at the household level.

\section{Identification of Household Heads}

There is no standardised definition for household headship in Latin American censuses, and its nature of self-declaration often incorporates an embedded social context of who ought to be considered as being in charge of the household. Household headship is loosely defined as the status of person recognized as such by other household members (IPUMS, 2016). The definition of headship has remained consistent over time, but earlier censuses tend to refer to the head of household as a male head, jefe, whereas more recent censuses, employ a gender-equal term, jefe o jefa, male or female household head, which may have affected the outcome by gender (Acosta-Díaz 2001; Ruíz Salguero \& Rodríguez Vignoli, 2011). In Figure 1, the columns of the histogram have been coloured to indicate the evolution of the exact wording of the census reference to household head: jefe (male head), jefe/jefa (male head/female head), jefa/jefe (female head/male head), or pessoa responsável (reference person). Although the more gender-neutral classifications may have contributed to a higher percentage of women self-reporting as head of household, the extent of its effect is vague as the timing of the most dramatic increases of female headship does not coincide with the years of the wording change for most countries, with the exceptions of Ecuador, Panama and Uruguay, where the greatest increases in female headship coincided with the timing of changes in census wording. For these countries, one needs to consider the effect of changes in census wording when interpreting the increasing propensity for women to self-declare as household head.

\section{Categorisation of union statuses}

We classified women and men into seven partnership or union statuses using the following variables in IPUMS: household type (hhtype), marital status (marst), consensual union status 
(consens), and children's (nchild) and spouse's (sploc) presence. The seven categories are: married with spouse present in the household; married with spouse absent from the household; in consensual union; single with no children; single with children; separated or divorced; and widowed. We distinguished between married women with spouse present and married women with spouse absent because it may have household headship and economic implications. We considered creating the same distinction for women in consensual unions, but the number of cohabiting women whose partner is not present in the household is negligible, usually below 4 per cent out of all cohabiting women. The presence of children in the household was used to distinguish between single women with and without children. Previous research has shown that single women with children typically are women who have cohabited in the past (Esteve, García, \& McCaa, 2011).

\section{Measurement of Living Conditions}

Our measurement of household living conditions is based on the building materials of dwelling, for example in roofing or flooring, and household amenities, such as the presence of a computer, refrigerator, or telephone. We constructed country-specific asset indices by dividing the number of assets present in the household by the total number of assets, which is similar to Hohmann and Garenne's approach (2009). Appendix 1 informs of the number of assets available to each country and reliability of each index. Appendix 2 provides details on the codification of each item. We did not use any particular weighting scheme to construct the indices. All assets had exactly the same weight because we are mainly interested in comparing female- versus male-headed households rather than differences across countries and over time. In addition, the theoretical literature on household welfare has not been sufficiently developed to provide a weighting scheme for each of the assets which would guarantee an accurate measurement of living conditions (Filmer \& Pritchett, 2001). The use of specific weights has been substantiated on statistical premises through the use of the principal components approach (Filmer \& Pritchett, 2001; Kolenikov \& Angeles, 2009). We have compared our results to those weighted by principal component analysis and found no significant differences between the two. A sensitivity analysis has been conducted to ensure the internal consistency of the variables for each index (results available from the authors). 
We created a dummy variable to measure whether a household scores below (1), or above or equal (0) to the mean of the asset index of each sample. Households that score lower than the mean of all households are coded as "living in poor conditions", and those that score the mean or above are coded as "not living in poor conditions." Due to the lack of consistency of available variables in censuses, we do not compare samples of different time points and neither do we compare countries with one another. Only the most recent samples are explored for this part of the analysis and each country is evaluated separately. This dummy variable serves as the dependent variable of a series of logistic regression models that include as independent variables: sex of the household head, union status, urban or rural setting, ownership of dwelling, and presence of children. Age and educational attainment (less than primary, primary completed, secondary completed, university completed), are used as controls (not shown in the models).

\section{Results}

\subsection{Evolution and Decomposition of Female Headship by Union Status}

Figure 1 shows trends in female headship rates for women aged from 35 to 44 in 14 Latin American countries over the past four decades. Trends are unambiguously increasing across all countries in the region. Female headship in Brazil more than tripled from 10.6 per cent in 1980 to 33.2 per cent in 2010 and, in Uruguay, rose from 14.9 in 1986 to 44.4 in 2011. In Chile, there were only 14.1 per cent of women-headed households in 1970 compared to 23.2 in 2002 . Similarly, 16.9 per cent of Venezuelan women headed households in 1971 compared to 24.1 in 2002. Female headship grew in Costa Rica from 13.1 to 25.9 per cent between 1973 and 2011.

The distribution of women aged from 35 to 44 by union status for the first and most recent available census is shown on the left side of Table 1, while the headship rates of these women appear on the right side. Table 1 provides the background information for determining whether the overall increase in headship rates is due to compositional or rate change. In all countries except in El Salvador, there is a drop in the percentage of women who are married and living with a spouse, and a rise in the percentage of women in consensual unions. The number of cohabiting women has tripled in 
countries like Brazil, Chile, and Uruguay and almost doubled in Argentina, Colombia, Costa Rica and Peru. More modest but still positive are the figures for increased cohabitation in countries like Panama, Venezuela and Ecuador. The incidence of divorce and separation has tripled in Brazil, Costa Rica, Nicaragua and Venezuela. In 1971, only 2.1 per cent of women aged between 35 and 44 were divorced or separated in Venezuela, compared to 12.2 per cent in 2001. In Brazil, the figure has more than tripled from 5.3 per cent in 1980 to 16.5 per cent in 2010 . As a result, we also find a rise in the numbers of single women with children at home. By contrast, the percentage of single women without children has shown negligible changes over recent decades and the percentage of widows has decreased everywhere.

[Table 1 here]

Table 1. Composition and headship rate by union status of women aged from 35 to 44 by union status, earlier and most recent census

Table 1 (right panel) shows headship rates within each union status. All countries follow a similar pattern: widowed women have the highest headship rate, followed by those who are separated or divorced, married with the spouse absent, and single but living with at least one child. Among women in unions, cohabiting women show higher headship rates than married women with the spouse present, members of the latter group being the least likely to head their households. In the most recent censuses, female headship has risen among married and cohabiting women across all countries but particularly in Brazil and Uruguay. Before the 1990 census round, headship rates among married women (with spouse in the household) were around or below 1 per cent. By 2011, headship rates among married women have reached levels as high as 31.6 per cent in Uruguay and 18.4 per cent in Brazil (2010). Headship rates among cohabiting women have risen as well, exceeding the 10 per cent level in all countries and reaching levels as high as 40.3 per cent in Uruguay (2011) and 31.6 per cent in Brazil (2011).

[Table 2 here] 
Table 2. Percentage of women aged from 35 to 44 heading households, observed and standardized by constant rate, and percentage increase of female headship attributable to changes in union status, years rounded

Next, we examine how family changes - including the rise in cohabitation, divorce and separation, non-marital child-bearing and lone motherhood-affected trends in female headship. In Table 2, we decompose the rise in female headship into compositional change (due to shifts from union status of lower propensity of headship to union status of higher propensity of headship) and rate change (due to more women self-reporting as household head regardless of union status). Table 2 shows the observed percentage of women heading households at different points in time on the left side and the standardized percentage of women heading households with the headship rate held constant on the right side. The standardization of headship rate over time by union status (holding the rate constant resulting in only compositional changes) shows that changes in union status account for less than 50 per cent of the overall surge in female headship. In other words, if headship rates had remained constant over the period studied, the percentage of women heading households would have increased by a figure of less than half of the observed rise with the exception of Colombia, Nicaragua and Peru, where the percentage of increase attributable to changes in union status is around 50 per cent (Colombia and Nicaragua) and 71 per cent (Peru). Rate change within union status categories contributes to more than half of the rise in female headship among women aged from 35 to 44. In El Salvador, Paraguay and Uruguay in particular, the rise of female headship is due to a higher incidence of women self-reporting as household head, since compositional change only accounts for 19.8 per cent, 15 per cent, and 16 per cent of total headship increase, respectively.

\subsection{Living Conditions by Sex of the Household Head}

Next, we evaluate the relationship between female headship and living conditions in 14 Latin American countries. In order to do so, we implement a series of logistic regression models to examine the probability of living in poor conditions (below the mean for living conditions in each country). We 
are mainly interested in seeing whether households headed by women are in worse living conditions than those headed by men. Independent variables are sex, union status, and the presence of children of the household head, urban or rural residence, and household ownership. Datasets are weighted with scaled weights to retain population characteristics without inflating the sample size. Married men living with a spouse are used as the reference category. We focus on the most recent available data for each country: Argentina 2001, Brazil 2010, Chile 2002, Colombia 2005, Costa Rica 2011, Ecuador 2010, El Salvador 2007, Mexico 2010, Nicaragua 2005, Panama 2010, Paraguay 2002, Peru 2007, Uruguay 2011, and Venezuela 2001. Argentina 2010 was dropped from the analysis because this particular dataset misses essential family relationship indicators.

Table 3 shows the results of three logistic regression models per country (M1, M2, and M3). Model 1 only accounts for the sex of the household head. Model 2 includes additional variables: sex, union status, presence of children of the household head, urban or rural setting, and ownership of dwelling. In Model 3, we added two interaction terms: one between the sex and union status of the household head and the other between sex of the household head and presence of children.

Model 1 shows that there is a statistically significant difference between the living conditions of female- and male-headed households in 10 of the 14 countries. In eight countries, namely Argentina, Brazil, Chile, Colombia, Costa Rica, Panama, Uruguay and Venezuela, female-headed households are shown to be disadvantaged. Male-headed households are shown as being in a poorer condition than female-headed households in El Salvador and Peru. The sex of the household head is not statistically significant in Ecuador, Mexico, Nicaragua, and Paraguay.

[Table 3 here]

Table 3. Living in poor conditions by sex, union status and presence of children of household head aged from 35 to 44

In Model 2 we control for union status, urban or rural setting, ownership of dwelling, and the presence of children. In all countries, urban households are less likely to have poor living conditions than rural ones. Ownership decreases the likelihood of poor conditions in all countries except Ecuador 
and Peru. Households with children are less materially poor, except in Argentina. The differences between male- and female-headed households diminished in Model 2, in the presence of the abovementioned controls. The only exception is Brazil, where female-headed households are still less advantaged than male-headed households. The results for all other countries show that female-headed households are either better off than male-headed households (Argentina, Ecuador, El Salvador, Mexico, Nicaragua, Panama, Paraguay, Peru, Venezuela) or that the effect of the sex of the household head is not significant. In other words, when union status, urban or rural setting, ownership, and the presence of children in the household head are accounted for, male-headed households are in poorer conditions than female-headed households. Union status explains most of the changes between Model 1 and Model 2. In general, married heads with the spouse present are better off than any other category. The worst living conditions are associated with single, separated, divorced or widowed heads of households but, as we see in Model 3, union status operates differently for women than for men, with women being more advantaged in most cases.

The interaction of sex and union status shows that, for almost all countries, female household heads tend to fare better than male heads in non-traditional relationship statuses (situations other than married with a present spouse) as shown in Model 3. When the interaction between sex and union status is significant, women are less likely (odds ratios below 1) than men to experience poor living conditions of the same union status, with single women in Chile as the exception. In 12 out of 14 countries, separated or divorced female heads are better off than separated or divorced male heads. The same applies when the household heads are married but the spouse is absent. The interaction between sex and presence of children is statistically significant in six countries. In five of these, the presence of children in households headed by women indicates worse living conditions than the presence of children in male-headed households.

\section{Conclusions}

Female household headship has been on the rise over the past forty years in Latin America. In this paper, we have shown that the percentage of women aged from 35 to 44 heading their households 
has increased across the 14 Latin America countries examined. Up to the 1970s, female headship rates hovered between 10 to 15 per cent. By 2010, in countries such as Brazil and Uruguay, more than 30 per cent of women reported that they were the household heads. We used direct standardization to decompose trends in female headship over time between compositional and rate change. By compositional change, we refer to (and control for) the increasing number of women aged from 35 to 44 shifting from marriage to less "traditional" family situations such as cohabitation, singlehood, and separation or divorce. Since unmarried women have always been more likely to head households than married women, the compositional change of union status has had a positive impact on the observed rise in female headship, although it is not the main driver. Other than in Peru, where the overall increase is moderate in any case, compositional change accounted for at most half, although in most countries, less than half, of the female headship increase. The main reason for the increase of female headship in Latin America, therefore, is rate change: the increasing tendency for women to self-report as household heads. Across all countries and union statuses, women in recent censuses were more likely to self-report as household heads compared to earlier ones. This especially applies to married women living with a spouse, who showed, in relative terms, the largest increases in female headship.

Although we assume that the change of the wording of questionnaires from a male-oriented to gender-neutral definition of headship may have had an impact on the increase of female headship, we cannot disregard the possibility that the evolution of attitudes regarding the independence of women or the prevalence of female headship may also have influenced such change in the wording. These trends can be contextualized within the recent changes in family life which some authors have linked with the preliminary traces of the second demographic transition theory (Covre-Sussai, Meuleman, Botterman, \& Matthijs, 2015; Esteve et al, 2012; Lesthaeghe, 2014; Pellegrino, Cabella, Paredes, Rollero \& Varela, 2008). This transition, precipitated amongst other factors by female emancipation in the society, would favour an increase in female headship rates, not only in family circumstances historically associated with female headship, but for all women, regardless of the family situation.

Our evidence finds a mixed relationship between female headship and living conditions. In eight of the 14 countries examined in this paper (Argentina, Brazil, Chile, Colombia, Costa Rica, 
Panama, Uruguay, and Venezuela) female-headed households show, overall, poorer living conditions than male-headed households, even after controlling for age and educational attainment. Among the remaining six countries, four showed no significant differences between male-and female-headed households (Ecuador, Mexico, Nicaragua, and Paraguay) and, in two, male-headed households were in worse conditions than female-headed ones (El Salvador and Peru). The inclusion of controls in the models has proven extremely important in explaining the gender gap in living conditions. The gap has become insignificant in four countries (Chile, Colombia, Costa Rica and Uruguay) for which the baseline model indicated worse conditions among female heads than male heads. In three countries (Argentina, Panama and Venezuela), the gap reverses in favour of women, leaving male-headed households at a disadvantage. Only in Brazil, Peru and El Salvador, controls do not change the direction and significance of the parameters. To sum up, the gap in living conditions between femaleand male-headed households reverses or disappears when we control for the union and the parenthood status of the household heads. Once the presence of spouse and/or children are held to be equal for both female and male householders, female-headed households are not more likely to be in poorer living conditions than male-headed households, with the single exception of Brazil.

Our data shows that when households are not headed by co-residing married couples, their living conditions are systematically worse, but the interaction between sex of the household head and union status shows that, in all these cases (i.e. singlehood, cohabitation, separation/divorce, widowhood), households headed by women are less likely to be residing in poorer conditions than those with male heads in the same circumstances. These results suggest that the relationship between female headship and poor living conditions cannot be generalized to all countries in Latin America. It also implies that, in those countries where the relationship does exist, the link between female headship and poverty is mainly attributable to the family circumstances of female versus male household heads. Furthermore, we find that across all family situations except marriage with the spouse present, female-headed households are systematically better off than male-headed households.

Another important finding is that households headed by married persons with the spouse present are systematically better off than any other type of household. From an economic perspective, 
this is explained because the economies of scale allow minimization of household costs maintaining the same level of utility, something that is less likely to occur in other family arrangements, such as households with a single, divorced or widowed parent (Wakita, Fitsimmons \& Liao 2000). However, this argument does not explain why cohabiting couples are disadvantaged compared to married ones. This happens in a society in which cohabitation is more widespread than in any other developing regions in the world. It could be argued that the lower degree of institutionalization of consensual couples versus married couples may lead to a lower investment in household assets. Some authors would support this argument (Brown, 2004; Manning and Lichter, 1996). Since we are using a crosssectional perspective, we cannot confirm whether there is a selective transition from cohabitation to marriage for individuals with greater economic power.

Overall, our results highlight the need to consider the complexity of family situations when drawing inferences regarding households headed by women (Alvarado Merino \& Lara, 2016; Klasen, Lechtenfeld, \& Povel, 2015). First, we have shown the evolution of diversifying conditions under which women self-report as household heads in 14 Latin American countries in the past few decades. Female headship has shifted from the historical pattern of single mothers to women who would represent a wider range of partnership statuses. Such heterogeneity may have also contributed towards eroding the link between female headship and poverty, which is far from universal, and where it does pertain, it is mainly driven by the fact that singlehood and lone parenthood is overwhelmingly more common among women than among men. We have shown that, regardless of sex, the living conditions of householders who are not married and who live with a spouse are worse than those in any other family situation, but there is no common pattern across countries as to which is the most disadvantaged family situation. We have not attempted to explain why in some countries there is no gap in living conditions between females and males and why it disappears or reverses in others. Some studies suggest major gender differences in the ways in which men and women accumulate household assets, and that women are more inclined to amass these resources (Blau \& Graham, 1990; Chant, 2003). Another explanation may relate to the unobserved heterogeneity among female householders, whereby only the women with enough income and those with more power to meet the challenges of 
heading a household would take on this role (Villarreal and Shin, 2008). This translates into a higher capacity for accumulating assets. But the differences across countries require understanding of the country-specific legislation regarding family and public protection. The regional differences in the marriage laws, in the norms surrounding access and transmission of the property of the dwelling and the land (Deere, Alvarado \& Twyman, 2012), welfare systems (Sunkel, 2007), limitations to consensual unions, and the rights to receive and provide social support, present a range of challenges and opportunities for one's capacity to accumulate assets on a household level. Further research on the differences in normative and legal systems is indispensable for identifying family situations that require social intervention.

These results challenge female headship or the lone mother per se as categories of concern in policies aimed at combatting poverty (Alvarado Merino \& Lara, 2016; Moser, 1993). Instead of focusing on these, policy makers should develop strategies that directly address the difficulties faced by single-earner household heads in accumulating assets (Ozawa \& Lee, 2006), while taking great care not to frame the issue as one of poor unmarried women. Whether or not families in Latin America are on the verge of breakdown should not be entirely determined by marital stability, but also by the strength of extended family ties and the social networks of individuals (Chant, 2002). The expansion of female headship may indicate a change of attitude favouring women's emancipatory process (Chant, 2015). However, the fact that when both spouses are present, women are still less likely than men to report as head serves as evidence that egalitarianism has yet to be achieved in the region, as women tend to underreport their de facto headship, especially when a male partner lives in the household (Chant, 2003; Moser, 1993).

The conclusions of our study are limited due to several constraints. First, a causal relationship between union status and living in poor conditions cannot be established due to the lack of comparable longitudinal data. Second, since we are using household materials and amenities to build asset indices as proxy indicators for poverty, our measurement of poverty differs from that in studies utilising income or expenditure. Asset indices mostly provide information on the physical household, and women are known to invest more money in the household than men (Chant, 2003) but we do not 
have information on social capital. Third, the issue of vulnerability also extends beyond asset ownership. The gender gap related with earning and labour force participation remains wide for most Latin American countries (ECLAC, 2014), and this deprives women of equal opportunities for fully realising their economic potential. If the question is whether women are disadvantaged or not, women living in male-headed households may be at a higher risk of poverty than those who are able to form their own households (Alvarado Merino \& Lara, 2016). Beyond income, equality encompasses selfdetermination, health, and basic rights (Chant, 2016) which, although beyond the scope of this paper, are pivotal for understanding family relationships and the well-being of women and children in Latin America. In order to enable a much needed and wider consideration of the structural causes of poverty (Alvarado Merino \& Lara, 2016), we contribute to the discussion on the living conditions of female headed households through a large empirical, quantitative approach from a cross-national comparative perspective, scrutinizing the diversity of family situations of women who head households over time. 


\section{References}

Acosta Díaz, F. (2001). “Jefatura de hogar femenina y bienestar familiar: resultados de la investigación empírica". Papeles de Población, 7(28), 1-97.

Alvarado Merino, G. \& Lara, J. (2016) "Feminization of Poverty". In C.L. Shehan (ed.) The Wiley Blackwell Encyclopedia of Family Studies, John Wiley \& Son, Inc. doi: 10.1002/9781119085621.wbefs389

Arias, E., \& De Vos, S. (1996). "Using Housing Items to Indicate Socioeconomic Status: Latin America". Social Indicators Research, 38(1), 53-80. doi:10.1007/bf00293786

Arias, E., \& Palloni, A. (1999). "Prevalence and Patterns of Female Headed Households in Latin America: 1970-1990”. Journal of Comparative Family Studies, 30(2), 257-79.

Arriagada, I. (2006). "Changes and Inequality in Latin American Families”. Journal of Comparative Family Studies, 37(4), 511-537.

Blau, F. D., \& Graham, J. W. (1990). "Black-White Differences in Wealth and Asset Composition". The Quarterly Journal of Economics, 105, 321-339

Booysen, F., van der Berg, S., Burger, R., Maltitz, M. von, \& Rand, G. du (2008). “Using an Asset Index to Assess Trends in Poverty in Seven Sub-Saharan African countries". World Development, 36(6), 1113-1130. doi:10.1016/j.worlddev.2007.10.008

Brown, S. L. (2004). Family structure and child well- being: the significance of parental cohabitation. Journal of Marriage and Family, 66(2), 351-367.

Buvinic, M., \& Gupta, G. R. (1997). "Female-Headed Households and Female-Maintained Families: Are They Worth Targeting to Reduce Poverty in Developing Countries?" Economic Development and Cultural Change, 45(2), 259-280. doi:10.1086/452273

Carter, M. R., \& Barrett, C. B. (2006). "The Economics of Poverty Traps and Persistent Poverty: An Asset-Based Approach". Journal of Development Studies, 42(2), 178-199. doi:10.1080/00220380500405261 
Castro, T., \& Juárez, F. (1995). "La influencia de la educación de la mujer sobre la fecundidad en América Latina: en busca de explicaciones”. Perspectivas Internacionales en Planificación Familiar, 4-10

Chant, S. (1997). "Women-Headed Households: Poorest of the Poor? Perspectives from Mexico, Costa Rica and the Philippines”. IDS Bulletin, 28(3), 26-48. doi:10.1111/j.17595436.1997.mp28003003.x

Chant, S. (2002) "Families on the Verge of Breakdown? Views on Contemporary Trends in Family life in Guanacaste, Costa Rica”. Journal of Developing Societies, 18 (2-3). pp. 109-148.

Chant, S. (2003). "Female Household Headship and the Feminisation of Poverty: Facts, Fictions and Forward Strategies”. Retrieved June 15, 2016, from http://eprints.lse.ac.uk/archive/00000574 Chant, S. (2007). Gender, Generation and Poverty: Exploring the "Feminisation of Poverty" in Africa, Asia and Latin America. Cheltenham: Elgar, Edward Publishing.

Chant, S. (2008). "The "Feminisation of Poverty" and the "Feminisation" of Anti-Poverty Programmes: Room for Revision?” The Journal of Development Studies, 44(2), 165-197. doi:10.1080/00220380701789810

Chant, S. (2009). "The "Feminisation of Poverty" in Costa Rica: To what Extent a Conundrum?" Bulletin of Latin American Research, 28(1), 19-43. doi:10.1111/j.1470-9856.2008.00288.x Chant, S. (2013). "Cities through a "Gender Lens": A Golden "Urban Age” for Women in the Global South?" Environment \& Urbanization, 25(1): 9-29. doi: 10.1177/0956247813477809

Chant, S. (2015) "Female Household Headship as an Asset? Interrogating the Intersections of Urbanisation, Gender, and Domestic Transformations". In C. Moser (Ed), Gender, Asset Accumulation and Just Cities: Pathways to Transformation (pp. 21-39). London: Routledge.

Chant, S. (2016). "Women, Girls and World Poverty: Empowerment, Equality or Essentialism?" International Development Planning Review, 38(1), 1-24. doi:10.3828/idpr.2016.1

Chant, S., \& McIlwaine, C. (2016). Cities, Slums and Gender in the Global South: Towards a Feminised Urban Future. United Kingdom: Routledge. 
Covre-Sussai, M., Meuleman, B., Botterman, S., \& Matthijs, K. (2015). "Traditional and Modern Cohabitation in Latin America”. Demographic Research, 32, 873-914. doi:10.4054/demres.2015.32.32

Damián, A. (2003). “Tendencias recientes de la pobreza con enfoque de género en América Latina”. Papeles de Población, 9(38), 27-76.

Datta, K., \& McIlwaine, C. (2000). "Empowered Leaders"? Perspectives on Women Heading Households in Latin America and Southern Africa". Gender \& Development, 8(3), 40-49. doi:10.1080/741923782

De Vos, S. (1987). "Latin American Households in Comparative Perspective". Population Studies, 41(3), 501-517. doi:10.1080/0032472031000143026

De Vos, S. (1995). Household Composition in Latin America. Springer Science \& Business Media.

Deere, C. D., Alvarado, G. E., \& Twyman, J. (2012). “Gender Inequality in Asset Ownership in Latin America: Female Owners vs Household Heads”. Development and Change, 43(2), 505-530. doi:10.1111/j.1467-7660.2012.01764.x

Economic Commission for Latin America and the Caribbean (ECLAC). (2014). Social panorama of Latin America. Retrieved from http://repositorio.cepal.org/bitstream/handle/11362/37627/4/S1420728_en.pdf

Esteve, A., García-Román, J., \& Lesthaeghe, R. (2012). “The Family Context of Cohabitation and Single Motherhood in Latin America”. Population and Development Review, 38(4), 707-727. doi:10.1111/j.1728-4457.2012.00533.x

Esteve, A., García, J., \& McCaa, R. (2011). “La enumeración de la soltería femenina en los censos de población: sesgo y propuesta de corrección”. Papeles De Población, 66, 9-40.

Esteve, A., López-Ruiz, L. Á., \& Spijker, J. (2013). “Disentangling how Educational Expansion Did Not Increase Women's Age at Union Formation in Latin America from 1970 to 2000”. Demographic Research, 28, 63-76. doi:10.4054/demres.2013.28.3

Filmer, D., \& Pritchett, L. H. (2001). "Estimating Wealth Effects without Expenditure Data-or Tears: An Application to Educational Enrolments in States of India”. Demography, 38(1), 115. doi:10.2307/3088292 
Finley, A. P. (2007). “The "Graying” of Mexico and Its Impact on Female-Headed Households: Theoretical and Methodological Considerations". Latin American Research Review, 42(3), 183-204. doi:10.1353/lar.2007.0032

Fussell, E., \& Palloni, A. (2004). "Persistent Marriage Regimes in Changing Times". Journal of Marriage and Family, 66(5), 1201-1213. doi:10.1111/j.0022-2445.2004.00087.x

Fuwa, N. (2000). "The Poverty and Heterogeneity among Female-Headed Households Revisited: The Case of Panama". World Development, 28(8), 1515-1542. doi:10.1016/s0305-750x(00)00036-x

García, B., \& Rojas, O. (2002). "Los hogares latinoamericanos durante la segunda mitad del siglo XX: una perspectiva sociodemográfica”. Estudios Demográficos y Urbanos, 50, 261-288.

Gimenez, M. E. (1987). “The Feminization of Poverty: Myth or Reality?” Critical Sociology, 14(3), 5-30. doi:10.1177/089692058701400302

Harttgen, K., \& Klasen, S. (2012). “A Household-Based Human Development Index”. World Development, 40(5), 878-899. doi:10.1016/j.worlddev.2011.09.011

Heaton, T. B., Forste, R., \& Otterstrom, S. M. (2002). "Family Transitions in Latin America: First Intercourse, First Union and First Birth”. International Journal of Population Geography, 8(1), 1-15. doi:10.1002/ijpg.234

Hohmann, S., \& Garenne, M. (2011). “Absolute versus Relative Measures of Poverty: Application to DHS African Surveys". Journal of US-China Public Administration, 8(7), 748-762.

IPUMS. (2016) “Relate: Relationship to Household Head”. Retrieved September 16, 2016, from https://international.ipums.org/international-action/variables/RELATE\#comparability_section

Kimenyi, M. S., \& Mbaku, J. M. (1995). "Female Headship, Feminization of Poverty and Welfare". Southern Economic Journal, 62(1), 44. doi:10.2307/1061374

Klasen, S., Lechtenfeld, T., \& Povel, F. (2015). “A Feminization of Vulnerability? Female Headship, Poverty, and Vulnerability in Thailand and Vietnam". World Development, 71, 36-53. doi:10.1016/j.worlddev.2013.11.003

Kolenikov, S., \& Angeles, G. (2009). Socioeconomic status measurement with discrete proxy variables: Is principal component analysis a reliable answer?. Review of Income and Wealth, $55(1), 128-165$. 
Laplante, B., Castro-Martín, T., Cortina, C., \& Martín-García, T. (2015). Childbearing within marriage and consensual union in Latin America, 1980-2010. Population and Development Review, 41(1), 85-108.

Lavrin, A. (1989). Sexuality and Marriage in Colonial Latin America. United States: University of Nebraska Press.

Lesthaeghe, R. (2014). “The Second Demographic Transition: A Concise Overview of its Development". Proceedings of the National Academy of Sciences, 111(51), 18112-18115. doi:10.1073/pnas.1420441111

Loza Torres, M., Vizcarra Bordi, I., Lutz Bachère, B., \& Quintanar Guadarrama, E. (2007). "Jefaturas de hogar: el desafío femenino ante la migración transnacional masculina en el sur del Estado de México". Migraciones Internacionales, 4(2), 33-60.

Manning, W. D., \& Lichter, D. T. (1996). Parental cohabitation and children's economic well-being. Journal of Marriage and the Family, 58(4), 998-1010. doi: 10.2307/353986

Marcoux, A. (1998). “The Feminization of Poverty: Claims, Facts, and Data Needs”. Population and Development Review, 24(1), 131. doi:10.2307/2808125

McKenzie, D. J. (2005). “Measuring Inequality with Asset Indicators”. Journal of Population Economics, 18(2), 229-260. doi:10.1007/s00148-005-0224-7

Medeiros, M., \& Costa, J. (2008). "Is There a Feminization of Poverty in Latin America?" World Development, 36(1), 115-127. doi:10.1016/j.worlddev.2007.02.011

Minnesota Population Center. Integrated Public Use Microdata Series, International: Version 6.4 [Machine-readable database]. Minneapolis: University of Minnesota, 2015.

Moghadam, V. M. (2005). “The “Feminization of Poverty” and Women's Human Rights”. Retrieved from http://www.cpahq.org/cpahq/cpadocs/Feminization_of_Poverty.pdf

Moser, C. (1993). Gender Planning and Development: Theory, Practice and Training. New York: Routledge.

Moser, C. (2010). "Moving beyond Gender and Poverty to Asset Accumulation: Evidence from LowIncome Households in Guayaquil, Ecuador". In S. Chant (ed.), The International Handbook of Gender and Poverty: Concepts, Research, Policy (pp. 391-398) Edward Elgar Publishing. 
Moser, C., \& Felton, A. (2009). "The Construction of an Asset Index Measuring Asset Accumulation in Ecuador". In T. Addison, D. Hulme, \& R. Kanbur (Eds.), Poverty dynamics: Interdisciplinary perspectives (pp. 102-127). Oxford: Oxford University Press.

Nathan, M., \& Paredes, M. (2012). "Jefatura femenina en los hogares uruguayos". Revista de Ciencias Sociales, 25(30), 75-94.

Osborne, C., Manning, W. D., \& Smock, P. J. (2007). "Married and Cohabiting Parents' Relationship Stability: A Focus on Race and Ethnicity". Journal of Marriage and Family, 69(5), 1345-1366. doi:10.1111/j.1741-3737.2007.00451.x

Ozawa, M.N. \& Lee, Y. (2006) "The Net Worth of Female-Headed Households: A Comparison to Other Types of Households". Family Relations, 55(1), 132-145. doi: 10.1111/j.17413729.2006.00362.x.

Pearce, D. (1978). "The Feminization of Poverty: Women, Work and Welfare”. The Urban \& Social Change Review, 11(1\&2).

Pellegrino, A., Cabella, W., Paredes, M., Pollero, R., \& Varela, C. (2008). De una transición a otra: la dinámica demográfica del Uruguay en el siglo XX. El Uruguay del siglo XX. La sociedad, Montevideo, Ediciones Banda Oriental.

Permanyer, I. (2013). "Using Census Data to Explore the Spatial Distribution of Human Development”. World Development, 46, 1-13. doi:10.1016/j.worlddev.2012.11.015

Quilodrán, J. (1999). "L’union libre en Amérique latine: Aspects récents d'un phénomène séculaire”. Cahiers québécois de démographie, 28(1-2), 53-80. doi:10.7202/010259ar

Quisumbing, A. R., Haddad, L., \& Peña, C. (2001). “Are women Overrepresented among the Poor? An Analysis of Poverty in 10 Developing Countries". Journal of Development Economics, 66(1), 225-269. doi:10.1016/s0304-3878(01)00152-3

Rodríguez Vignoli, J. A. (2009). Reproducción adolescente y desigualdades en América Latina y el Caribe: un llamado a la reflexión y a la acción. Retrieved from http://www.oij.org/file_upload/publicationsItems/document/EJ1264091957.pdf 
Ruíz Salguero, M., \& Rodríguez Vignoli, J. A. (2011). Familia y nupcialidad en los censos latinoamericanos recientes: una realidad que desborda los datos. Retrieved from http://repositorio.cepal.org/bitstream/handle/11362/7133/S1001052_es.pdf?sequence=1

Sana, M., \& Massey, D. S. (2005). "Household Composition, Family Migration, and Community Context: Migrant Remittances in Four Countries”. Social Science Quarterly, 86(2), 509-528. doi:10.1111/j.0038-4941.2005.00315.x

Socolow, S. M. (2000). The Women of Colonial Latin America. Cambridge, UK: Cambridge University Press.

Sunkel, G. (2007) "Regímenes de bienestar y políticas de familia en América Latina” In Arriagada, I.

(Ed). Familias y políticas públicas en América Latina: una historia de desencuentros (Vol. 96). United Nations Publications

Stromquist, N. P. (ed.). (1998). Women in the Third world: An Encyclopedia of Contemporary Issues. New York: Garland Publishing.

Villarreal, A., \& Shin, H. (2008). "Unraveling the Economic Paradox of Female-Headed Households in Mexico: The Role of Family Networks”. Sociological Quarterly, 49(3), 565-595. doi:10.1111/j.1533-8525.2008.00128.x

Wakita, S., Fitzsimmons, V. S., \& Liao, T. F. (2000). Wealth: Determinants of savings net worth and housing net worth of pre-retired households. Journal of Family and Economic Issues, 21(4), 387-418. doi:10.1023/A:1026432705410 
Figure 1. Percentage of women aged from 35 to 44 heading households from 1970 to 2010
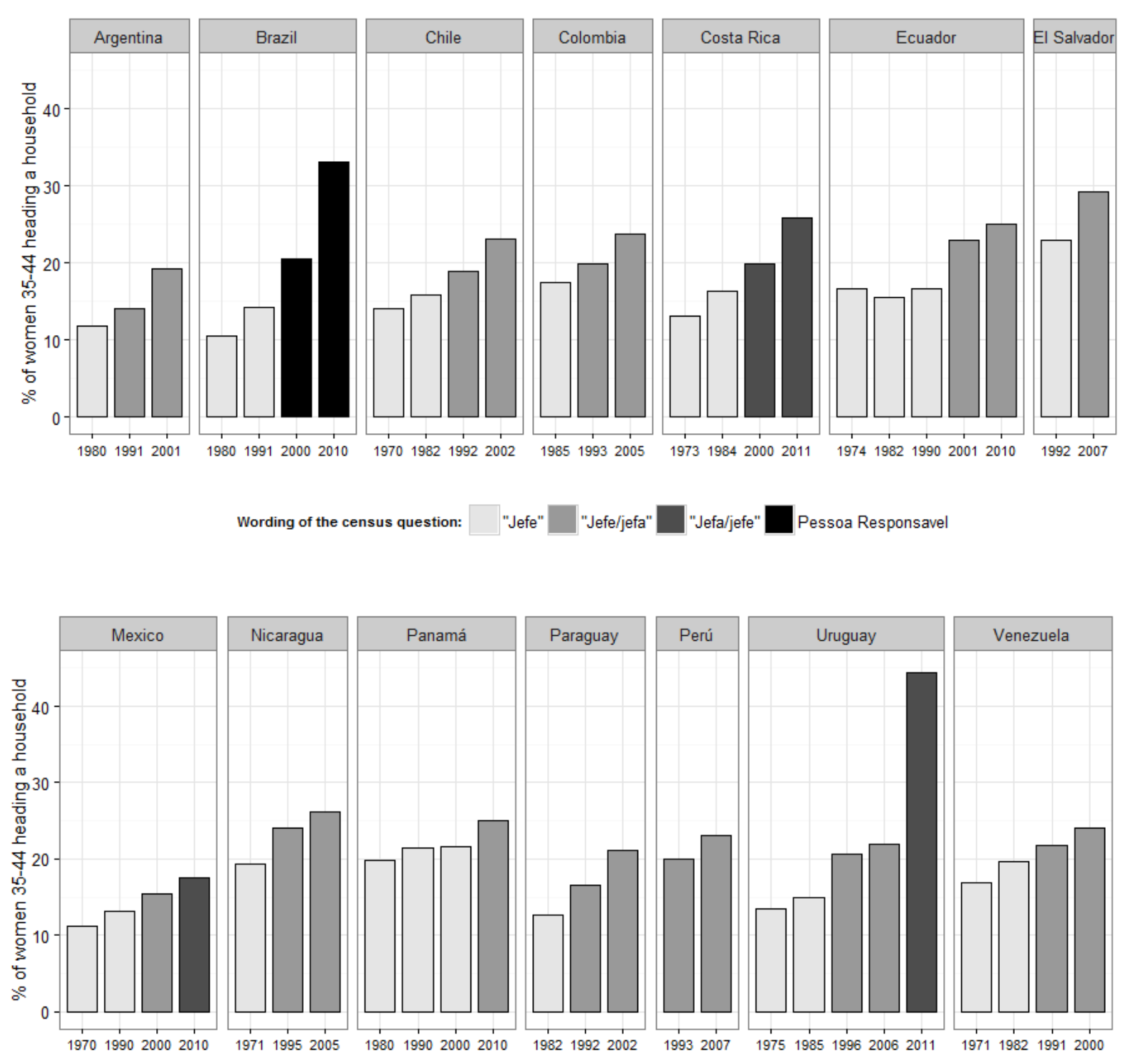

Source: IPUMS-International 
Table 1. Composition and headship rate by union status of women aged from 35 to 44 by union status, earlier and most recent census

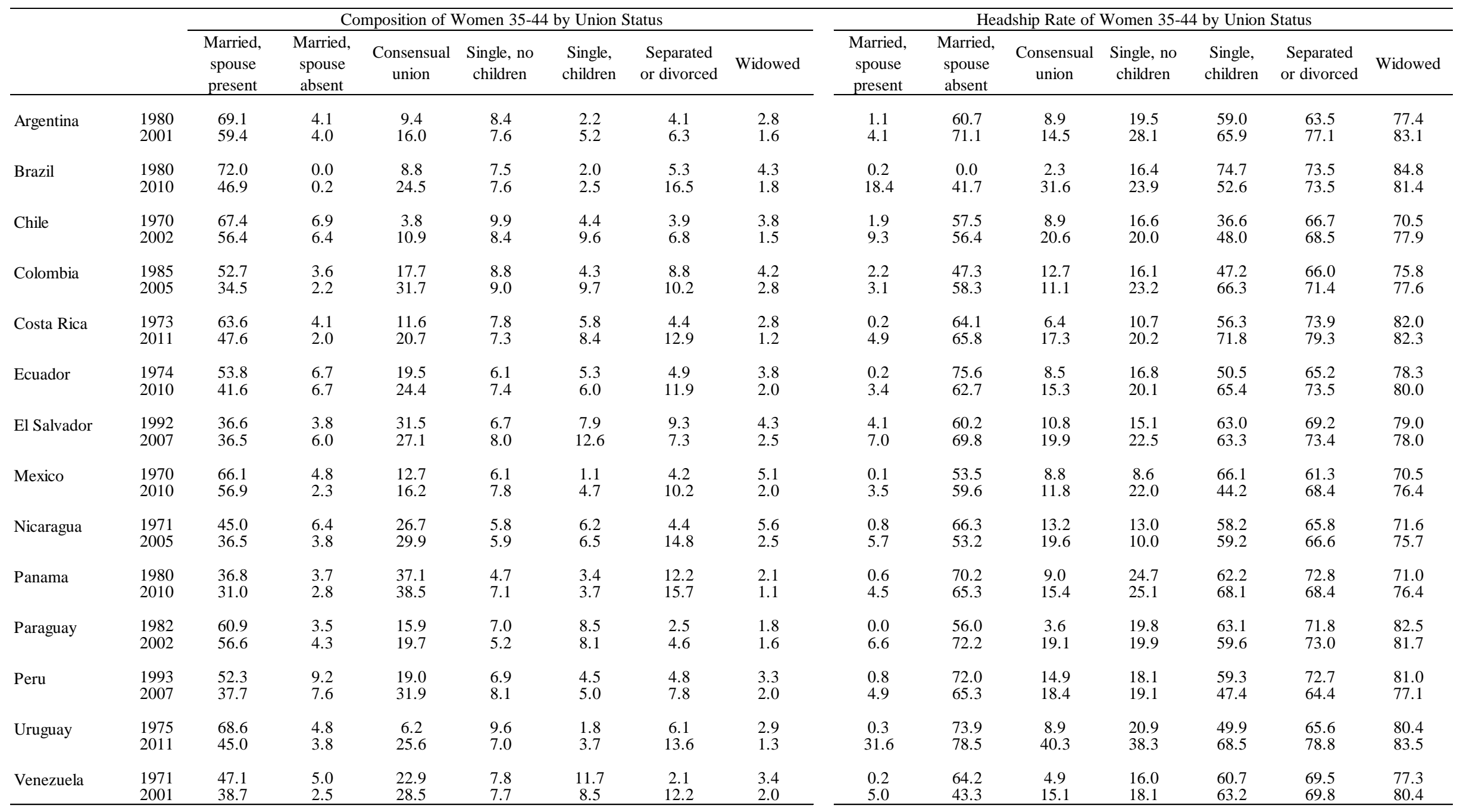

Source: IPUMS-International 
Table 2. Percentage of women aged from 35 to 44 heading households, observed and standardized by constant rate, and percentage of female headship increase attributable to change in union status, years rounded.

\begin{tabular}{|c|c|c|c|c|c|c|c|c|c|c|c|}
\hline & \multicolumn{5}{|c|}{ Observed Percentage of Women Heading Household } & \multicolumn{5}{|c|}{ Standardized percentage, reflecting only change in union status } & \multirow{2}{*}{$\begin{array}{c}\text { Percentage of Increase } \\
\text { Attributable to Change in } \\
\text { Union Status }\end{array}$} \\
\hline & $1970 \mathrm{~s}$ & $1980 \mathrm{~s}$ & $1990 \mathrm{~s}$ & $2000 \mathrm{~s}$ & $2010 \mathrm{~s}$ & $1970 \mathrm{~s}$ & $1980 \mathrm{~s}$ & $1990 \mathrm{~s}$ & $2000 \mathrm{~s}$ & $2010 \mathrm{~s}$ & \\
\hline Argentina & & 11.8 & 14.1 & 19.3 & & & 11.8 & 12.5 & 14.3 & & 0.34 \\
\hline Brazil & & 10.6 & 14.3 & 20.6 & 33.2 & & 10.6 & 13.4 & 16.0 & 17.4 & 0.30 \\
\hline Chile & 14.1 & 15.7 & 18.9 & 23.2 & & 14.1 & 14.3 & 15.0 & 16.2 & & 0.23 \\
\hline Colombia & & 17.5 & 19.9 & 23.8 & & & 17.5 & 19.3 & 20.7 & & 0.50 \\
\hline Costa Rica & 13.1 & 16.4 & & 19.9 & 25.9 & 13.1 & 15.2 & & 16.1 & 18.7 & 0.44 \\
\hline Ecuador & 16.7 & 15.5 & 16.6 & 23.0 & 25.1 & 16.7 & 15.3 & 15.5 & 18.8 & 20.8 & 0.49 \\
\hline E1 Salvador & & & 22.9 & & 29.2 & & & 22.9 & & 24.2 & 0.20 \\
\hline Mexico & 11.2 & & 13.2 & 15.5 & 17.5 & 11.2 & & 10.7 & 12.5 & 14.1 & 0.47 \\
\hline Nicaragua & 19.4 & & 24.0 & 26.2 & & 19.4 & & 23.1 & 22.9 & & 0.51 \\
\hline Panama & & 19.8 & 21.5 & 21.7 & 25.1 & & 19.8 & 21.1 & 21.3 & 21.9 & 0.40 \\
\hline Paraguay & & 12.6 & 16.6 & 21.1 & & & 12.6 & 12.7 & 13.9 & & 0.15 \\
\hline Peru & & & 20.0 & 23.1 & & & & 20.0 & 22.2 & & 0.71 \\
\hline Uruguay & 13.5 & 14.9 & 20.6 & 22.0 & 44.4 & 13.5 & 14.3 & 15.5 & 16.2 & 18.4 & 0.16 \\
\hline Venezuela & 16.9 & 19.6 & 21.8 & 24.1 & & 16.9 & 17.9 & 19.0 & 19.5 & & 0.36 \\
\hline
\end{tabular}

Source: IPUMS-I International 
Table 3. Odds ratio of living in poor conditions by sex, union status, presence of children of household head, urban or rural residence, ownership of dwelling, of household heads aged 35 to 44

\begin{tabular}{|c|c|c|c|c|c|c|c|c|c|c|c|c|c|c|c|c|c|c|c|c|c|}
\hline \multirow[b]{2}{*}{ Model } & \multicolumn{3}{|c|}{ Argentina } & \multicolumn{3}{|c|}{ Brazil } & \multicolumn{3}{|c|}{ Chile } & \multicolumn{3}{|c|}{ Colombia } & \multicolumn{3}{|c|}{ Costa Rica } & \multicolumn{3}{|c|}{ Ecuador } & \multicolumn{3}{|c|}{ El Salvador } \\
\hline & M1 & M2 & M3 & M1 & M2 & M3 & M1 & M2 & M3 & M1 & M2 & M3 & M1 & M2 & M3 & M1 & M2 & M3 & M1 & M2 & M3 \\
\hline $\begin{array}{l}\text { Sex } \\
\text { Male (ref) }\end{array}$ & & & & & & & & & & & & & & & & & & & & & \\
\hline Male (ref) & 1.00 & 1.00 & 1.00 & 1.00 & 1.00 & 1.00 & 1.00 & 1.00 & 1.00 & 1.00 & 1.00 & 1.00 & 1.00 & 1.00 & 1.00 & 1.00 & 1.00 & 1.00 & 1.00 & 1.00 & 1.00 \\
\hline $\begin{array}{l}\text { Female } \\
\text { Union Status }\end{array}$ & $1.41^{* * *}$ & $* 0.89 * *$ & $1.80^{* * *}$ & $1.71 * * *$ & $1.23^{* * * *}$ & * $1.42 * *$ & $1.31 * * *$ & $* 0.97$ & 0.87 & $1.32^{* * * *}$ & * 0.92 & 0.97 & $1.65^{* * *}$ & $* 0.96$ & 0.99 & 1.03 & $0.77 * * *$ & $* 0.83$ & $0.81 * * *$ & $* 0.69 * *$ & $* 0.58 *$ \\
\hline Married, spouse pres (ref) & & 1.00 & 1.00 & & 1.00 & 1.00 & & 1.00 & 1.00 & & 1.00 & 1.00 & & 1.00 & 1.00 & & 1.00 & 1.00 & & 1.00 & 1.00 \\
\hline Married, spouse absent & & $2.20 * * *$ & $3.53 * * *$ & & 1.61 & 1.84 & & $1.28 * * *$ & $* 1.65 * * *$ & & $1.59 * * *$ & $* 2.19 * * *$ & & $3.17 * * *$ & * 4.79*** & & $1.20 * *$ & $1.48^{* * * *}$ & & $0.82^{*}$ & 1.12 \\
\hline Consen union & & $1.99 * * *$ & * $2.03 * * *$ & & $2.14 * * *$ & $* 2.21 * * *$ & & $2.15 * * *$ & $* 2.24 * * *$ & & $1.83 * * *$ & $* 1.79 * * *$ & & $2.64 * * *$ & $* 2.70 * * *$ & & $2.36^{* * * *}$ & $* 2.40 * * *$ & & $1.83^{* * *}$ & $* 1.90 * * *$ \\
\hline Single & & $3.30 * * *$ & $3.87 * * *$ & & $2.56^{* * * *}$ & $* 2.88 * * *$ & & $2.08 * * *$ & $* 1.75 * * *$ & & $2.75^{* * *}$ & *3.62**** & & $3.51 * * *$ & $* 3.00 * * *$ & & $2.48^{* * * *}$ & $* 2.66 * * *$ & & $1.94 * * *$ & $* 1.78 * * *$ \\
\hline Separated or divorced & & $1.59 * * *$ & 2.19 *** & & $3.15^{* * *}$ & $* 3.44 * * *$ & & $1.90 * * *$ & $* 2.27 * * *$ & & $2.15 * * *$ & $* 2.94 * * *$ & & $2.57 * * *$ & $* 2.75 * * *$ & & $2.45 * * *$ & $* 2.82 * * *$ & & $1.63^{* * *}$ & $* 1.51 *$ \\
\hline $\begin{array}{l}\text { Widowed } \\
\text { Children }\end{array}$ & & $1.67 * * *$ & $1.70 *$ & & $2.44 * * *$ & $* 3.18 * * *$ & & $2.09 * * *$ & $* 1.76$ & & $2.30^{* * *}$ & $* 5.84 * * *$ & & $2.16^{* * *}$ & $* 4.57 * * *$ & & $2.35 * * *$ & * $2.95 * * *$ & & $1.96 * *$ & $* 2.91 * *$ \\
\hline $\begin{array}{l}\text { No (ref) } \\
\text { Yes }\end{array}$ & & 1.00 & $\begin{array}{l}1.00 \\
1.23 * * *\end{array}$ & & $\begin{array}{l}1.00 \\
0.60 * * *\end{array}$ & $\begin{array}{l}1.00 \\
* 070 * *\end{array}$ & & 1.00 & $\begin{array}{l}1.00 \\
* 07 * * *\end{array}$ & & 1.00 & $\begin{array}{l}1.00 \\
* 073 * *\end{array}$ & & 1.00 & $\begin{array}{l}1.00 \\
* 07 * * *\end{array}$ & & 1.00 & $\begin{array}{l}1.00 \\
* 0.05 * *\end{array}$ & & $\begin{array}{l}1.00 \\
0.09\end{array}$ & 1.00 \\
\hline $\begin{array}{l}\text { Yes } \\
\text { Urban }\end{array}$ & & $1.12^{* *}$ & $1.23^{* * * *}$ & & $0.69^{* * *}$ & $* 0.70^{* * *}$ & & $0.78^{* * *}$ & $* 0.74 * * *$ & & $0.67 * * *$ & $* 0.73 * * *$ & & $0.80^{* * *}$ & $* 0.77^{* * *}$ & & $0.83^{* * * *}$ & $* 0.85 * *$ & & 0.99 & 0.89 \\
\hline No (ref) & & 1.00 & 1.00 & & 1.00 & 1.00 & & 1.00 & 1.00 & & 1.00 & 1.00 & & 1.00 & 1.00 & & 1.00 & 1.00 & & 1.00 & 1.00 \\
\hline Yes & & $0.34 * * *$ & $0.35 * * *$ & & $0.22^{* * *}$ & $* 0.22 * * *$ & & $0.23 * * *$ & $* 0.24 * * *$ & & $0.10^{* * *}$ & $* 0.10^{* * *}$ & & $0.43 * * *$ & $* 0.42 * * *$ & & $0.26^{* * *}$ & $* 0.23 * * *$ & & $0.10^{* * *}$ & $* 0.10$ *** \\
\hline Ownership & & & & & & & & & & & & & & & & & & & & & \\
\hline No (ref) & & 1.00 & 1.00 & & 1.00 & 1.00 & & 1.00 & 1.00 & & 1.00 & 1.00 & & 1.00 & 1.00 & & 1.00 & 1.00 & & 1.00 & 1.00 \\
\hline Yes & & $0.84 * * *$ & $0.83 * * *$ & & $0.76^{* * *}$ & $* 0.77 * * *$ & & $0.86 * * *$ & $* 0.86^{* * *}$ & & 1.01 & 0.97 & & $0.45^{* * *}$ & $* 0.44 * * *$ & & $1.67^{* * * *}$ & $* 1.67 * * *$ & & $0.83^{* * *}$ & $* 0.79 * * *$ \\
\hline Interaction & & & & & & & & & & & & & & & & & & & & & \\
\hline Female $\mathrm{x}$ married, $\mathrm{ab}$ & & & $0.34 * * *$ & & & 0.76 & & & $0.66 * *$ & & & $0.37 * *$ & & & $0.43^{* *}$ & & & $0.52 * * *$ & & & $0.52 * *$ \\
\hline Female $\mathrm{x}$ consens & & & $0.66^{* * *}$ & & & $0.89^{*}$ & & & 0.81 & & & 0.93 & & & $0.71 * *$ & & & $0.74 * *$ & & & $0.70^{*}$ \\
\hline Female $\mathrm{x}$ single & & & $0.54 * * *$ & & & $0.79 * *$ & & & $1.32^{* *}$ & & & $0.42^{* * *}$ & & & 1.00 & & & $0.63^{* *}$ & & & 0.87 \\
\hline Female $x$ sep div & & & $0.44 * * *$ & & & $0.83 * *$ & & & $0.75^{*}$ & & & $0.40^{* * *}$ & & & $0.72 *$ & & & $0.56^{* * *}$ & & & 0.85 \\
\hline Female $\mathrm{x}$ widow & & & 0.63 & & & 0.69 & & & 1.16 & & & $0.22 * * *$ & & & $0.33^{* *}$ & & & $0.53^{* *}$ & & & 0.49 \\
\hline Female $\mathrm{x}$ child & & & 0.98 & & & 1.00 & & & $1.24 *$ & & & 1.19 & & & 1.14 & & & 1.10 & & & $1.36^{*}$ \\
\hline
\end{tabular}

$\mathrm{p}<0.05^{*}, \mathrm{p}<0.01^{* *}, \mathrm{p}<0.001 * * *$. Age and educational attainment controlled for all models 
Table 3 Continued

\begin{tabular}{|c|c|c|c|c|c|c|c|c|c|c|c|c|c|c|c|c|c|c|c|c|c|}
\hline \multirow[b]{2}{*}{ Model } & \multicolumn{3}{|c|}{ Mexico } & \multicolumn{3}{|c|}{ Nicaragua } & \multicolumn{3}{|c|}{ Panama } & \multicolumn{3}{|c|}{ Paraguay } & \multicolumn{3}{|c|}{ Peru } & \multicolumn{3}{|c|}{ Uruguay } & \multicolumn{3}{|c|}{ Venezuela } \\
\hline & M1 & M2 & M3 & M1 & M2 & M3 & M1 & M2 & M3 & M1 & M2 & M3 & M1 & M2 & M3 & M1 & M2 & M3 & M1 & M2 & M3 \\
\hline $\begin{array}{l}\text { Sex } \\
\text { Male (ref) }\end{array}$ & 1.00 & 1.00 & 1.00 & 1.00 & 1.00 & 1.00 & 1.00 & 1.00 & 1.00 & 1.00 & 1.00 & 1.00 & 1.00 & 1.00 & 1.00 & 1.00 & 1.00 & 1.00 & 1.00 & 1.00 & 1.00 \\
\hline $\begin{array}{l}\text { Male (ret) } \\
\text { Female }\end{array}$ & 0.96 & $0.75 * * *$ & $* 0.58 *$ & 0.99 & $0.83 * *$ & 0.62 & $1.33^{* * *}$ & $0.80 * * *$ & $* 0.83$ & 1.05 & 0.80 *** & $* 0.91$ & $0.80 * * *$ & $* 0.67 * * *$ & $0.59 *$ & $1.27 * * *$ & * 1.06 & 1.09 & $1.17^{* *}$ & $* 0.73 * *$ & $* 0.46 * *$ \\
\hline Union Status & & & & & & & & & & & & & & & & & & & & & \\
\hline Married, spouse pres (ref) & & 1.00 & 1.00 & & 1.00 & 1.00 & & 1.00 & 1.00 & & 1.00 & 1.00 & & 1.00 & 1.00 & & 1.00 & 1.00 & & 1.00 & 1.00 \\
\hline Married, spouse absent & & 1.12 & 1.30 & & 0.85 & 1.01 & & $2.07 * * *$ & $* 2.24 * * *$ & & $1.46^{* * * *}$ & $* 1.81 * * *$ & & $1.42 * * *$ & ${ }^{*} 1.87^{* * * *}$ & & $3.33 * * *$ & $* 4.20$ *** & & $2.16^{* *}$ & * 2.40 *** \\
\hline Consen union & & $1.76^{* * * *}$ & $* 1.75^{* * *}$ & & $1.63^{* * *}$ & $* 1.64 * * *$ & & $2.53 * * *$ & $* 2.44 * * *$ & & $1.83 * * *$ & $* 1.85^{* * *}$ & & $1.64 * * *$ & $1.61 * * *$ & & $2.31 * * *$ & $* 2.34 * * *$ & & $2.40^{* * *}$ & $* 2.43 * * *$ \\
\hline Single & & $1.71 * * *$ & $* 1.41 * *$ & & $1.66^{* * *}$ & * $1.91 * *$ & & $4.40^{* * *}$ & $* 5.61 * * *$ & & $2.22 * * *$ & $* 3.21 * * *$ & & $1.60^{* * *}$ & $1.65^{* * *}$ & & $4.16^{* * *}$ & $* 4.79 * * *$ & & $3.28^{* *}$ & $* 3.39 * * *$ \\
\hline Separated or divorced & & $1.67^{* * *}$ & $* 2.16^{* * *}$ & & $1.60^{* * *}$ & * $2.15 * *$ & & $4.12 * * *$ & $* 5.56 * * *$ & & $1.61 * * *$ & $* 2.42 * * *$ & & $1.94 * * *$ & $1.82^{* * * *}$ & & $3.51 * * *$ & $* 4.24 * * *$ & & $2.63^{* * *}$ & $* 3.49 * * *$ \\
\hline Widowed & & $1.55^{* *}$ & $2.00 *$ & & $1.82 * *$ & $3.07^{*}$ & & $3.11 * * *$ & $* 3.62 * *$ & & $1.72 * * *$ & $* 2.68 * *$ & & $1.89 * * *$ & *2.14** & & $3.42 * * *$ & $* 7.84 * * *$ & & 2.37 ** & $* 2.47 * *$ \\
\hline Children & & & & & & & & & & & & & & & & & & & & & \\
\hline No (ref) & & 1.00 & 1.00 & & 1.00 & 1.00 & & 1.00 & 1.00 & & 1.00 & 1.00 & & 1.00 & 1.00 & & 1.00 & 1.00 & & 1.00 & 1.00 \\
\hline $\begin{array}{l}\text { Yes } \\
\text { Urban }\end{array}$ & & $0.78 * * *$ & $* 0.75 * * *$ & & 0.90 & 0.85 & & $0.88 * *$ & 0.97 & & $0.87 *$ & 0.97 & & $0.64 * * *$ & $0.64 * * *$ & & $0.80 * * *$ & $* 0.84 * *$ & & $0.82^{* *}$ & $* 0.79 * *$ \\
\hline No (ref) & & 1.00 & 1.00 & & 1.00 & 1.00 & & 1.00 & 1.00 & & 1.00 & 1.00 & & 1.00 & 1.00 & & -- & 1.00 & & 1.00 & 1.00 \\
\hline $\begin{array}{l}\text { Yes } \\
\text { Ownership }\end{array}$ & & $0.18 * * *$ & $* 0.17 * * *$ & & $0.12 * * *$ & $* 0.11 * * *$ & & $0.20 * * *$ & $* 0.20 * * *$ & & $0.11 * * *$ & $* 0.11 * * *$ & & $0.02 * * *$ & $0.02 * * *$ & & -- & -- & & $0.19^{* *}$ & $* 0.17 * * *$ \\
\hline No (ref) & & 1.00 & 1.00 & & 1.00 & 1.00 & & 1.00 & 1.00 & & 1.00 & 1.00 & & 1.00 & 1.00 & & 1.00 & 1.00 & & 1.00 & 1.00 \\
\hline Yes & & $0.77^{* * * *}$ & $* 0.76$ *** & & $0.71 * * *$ & $* 0.70^{* * *}$ & & $0.83^{* * *}$ & $* 0.80^{* * *}$ & & 0.95 & 0.98 & & $1.15^{* * *}$ & $1.17^{* * *}$ & & $0.68 * * *$ & $* 0.65 * * *$ & & $0.84^{* *}$ & $* 0.81 * * *$ \\
\hline Interaction & & & & & & & & & & & & & & & & & & & & & \\
\hline Female $\mathrm{x}$ married, $\mathrm{ab}$ & & & 0.73 & & & 0.58 & & & 0.82 & & & $0.57 * *$ & & & $0.64 * *$ & & & $0.69^{*}$ & & & $0.59 *$ \\
\hline Female $\mathrm{x}$ consens & & & 0.92 & & & 0.79 & & & 1.20 & & & 0.83 & & & 1.01 & & & 0.97 & & & $0.72 * *$ \\
\hline Female $\mathrm{x}$ single & & & 1.36 & & & 0.62 & & & $0.59 *$ & & & $0.44 * * *$ & & & 0.94 & & & 0.80 & & & $0.68 * *$ \\
\hline Female $\mathrm{x}$ sep div & & & $0.63 * *$ & & & $0.52 *$ & & & $0.62 *$ & & & $0.43^{* * *}$ & & & 1.06 & & & $0.74 * *$ & & & $0.48 * * *$ \\
\hline Female $\mathrm{x}$ widow & & & 0.65 & & & 0.42 & & & 0.74 & & & $0.45^{*}$ & & & 0.84 & & & $0.36^{*}$ & & & 0.65 \\
\hline Female $x$ child & & & $1.32 *$ & & & $1.69 *$ & & & 0.94 & & & 1.20 & & & 1.10 & & & 1.04 & & & $1.44 * *$ \\
\hline
\end{tabular}

$\mathrm{p}<0.05^{*}, \mathrm{p}<0.01^{* *}, \mathrm{p}<0.001^{* * *}$. Age and educational attainment controlled for all models. 
Appendix 1. Components of the asset indices

\begin{tabular}{|c|c|c|c|c|c|c|c|c|c|c|c|c|c|c|}
\hline & $\begin{array}{c}\text { Argentina } \\
2001\end{array}$ & $\begin{array}{c}\text { Brazil } \\
2010 \\
\end{array}$ & $\begin{array}{l}\text { Chile } \\
2002\end{array}$ & $\begin{array}{c}\text { Colombia } \\
2005\end{array}$ & $\begin{array}{c}\text { Costa Rica } \\
2011 \\
\end{array}$ & $\begin{array}{c}\text { Ecuador } \\
2010\end{array}$ & $\begin{array}{c}\text { El Salvador } \\
2007\end{array}$ & $\begin{array}{c}\text { Mexico } \\
2010\end{array}$ & $\begin{array}{l}\text { Nicaragua } \\
2005\end{array}$ & $\begin{array}{c}\text { Paraguay } \\
2002\end{array}$ & $\begin{array}{c}\text { Panama } \\
2010\end{array}$ & $\begin{array}{l}\text { Peru } \\
2007\end{array}$ & $\begin{array}{l}\text { Uruguay } \\
2011\end{array}$ & $\begin{array}{c}\text { Venezuela } \\
2001\end{array}$ \\
\hline sewage & $\mathrm{x}$ & & $\mathrm{x}$ & & $\mathrm{x}$ & $\mathrm{x}$ & $\mathrm{x}$ & & $\mathrm{x}$ & $\mathrm{x}$ & $\mathrm{x}$ & $\mathrm{x}$ & & $\mathrm{x}$ \\
\hline cooking fuel & $\mathrm{x}$ & & & $\mathrm{x}$ & $\mathrm{x}$ & $\mathrm{x}$ & $\mathrm{x}$ & $\mathrm{x}$ & $\mathrm{x}$ & $\mathrm{x}$ & $\mathrm{x}$ & $\mathrm{x}$ & & $\mathrm{x}$ \\
\hline $\begin{array}{l}\text { refrigerator } \\
\text { automobiles }\end{array}$ & $\mathrm{x}$ & $\mathrm{x}$ & $\mathrm{x}$ & $\mathrm{x}$ & & & $\mathrm{x}$ & $\mathrm{x}$ & $\mathrm{x}$ & $\mathrm{x}$ & $\mathrm{x}$ & $\mathrm{x}$ & $\mathrm{x}$ & $\mathrm{x}$ \\
\hline available & & $\mathrm{x}$ & $\mathrm{x}$ & $\mathrm{x}$ & $\mathrm{x}$ & & $\mathrm{x}$ & $\mathrm{x}$ & $\mathrm{x}$ & $\mathrm{x}$ & $\mathrm{x}$ & & $\mathrm{x}$ & \\
\hline $\begin{array}{l}\text { computer } \\
\text { cellular phone }\end{array}$ & $\mathrm{x}$ & $\mathrm{x}$ & $\mathrm{x}$ & $\mathrm{x}$ & $\mathrm{x}$ & $\mathrm{x}$ & $\mathrm{x}$ & $\mathrm{x}$ & $\mathrm{x}$ & $\mathrm{x}$ & $\mathrm{x}$ & $\mathrm{x}$ & $\mathrm{x}$ & $\mathrm{x}$ \\
\hline available & $\mathrm{x}$ & $\mathrm{x}$ & $\mathrm{x}$ & & $\mathrm{x}$ & $\mathrm{x}$ & $\mathrm{x}$ & $\mathrm{x}$ & $\mathrm{x}$ & $\mathrm{x}$ & $\mathrm{x}$ & $\mathrm{x}$ & & \\
\hline floor material & $\mathrm{x}$ & & $\mathrm{x}$ & $\mathrm{x}$ & $\mathrm{x}$ & $\mathrm{x}$ & $\mathrm{x}$ & $\mathrm{x}$ & $\mathrm{x}$ & $\mathrm{x}$ & $\mathrm{x}$ & $\mathrm{x}$ & & $\mathrm{x}$ \\
\hline $\begin{array}{l}\text { electricity } \\
\text { wall or building }\end{array}$ & & $\mathrm{x}$ & $\mathrm{x}$ & $\mathrm{x}$ & $\mathrm{x}$ & $\mathrm{x}$ & $\mathrm{x}$ & $\mathrm{x}$ & $\mathrm{x}$ & $\mathrm{x}$ & $\mathrm{x}$ & $\mathrm{x}$ & & $\mathrm{x}$ \\
\hline $\begin{array}{l}\text { material } \\
\text { telephone }\end{array}$ & & & & $\mathrm{x}$ & $\mathrm{x}$ & & & $\mathrm{x}$ & & $\mathrm{x}$ & & & & \\
\hline availability & $\mathrm{x}$ & $\mathrm{x}$ & $\mathrm{x}$ & $\mathrm{x}$ & $\mathrm{x}$ & $\mathrm{x}$ & $\mathrm{x}$ & $\mathrm{x}$ & $\mathrm{x}$ & $\mathrm{x}$ & $\mathrm{x}$ & $\mathrm{x}$ & $\mathrm{x}$ & $\mathrm{x}$ \\
\hline water & $\mathrm{x}$ & $\mathrm{x}$ & $\mathrm{x}$ & $\mathrm{x}$ & $\mathrm{x}$ & $\mathrm{x}$ & $\mathrm{x}$ & $\mathrm{x}$ & $\mathrm{x}$ & $\mathrm{x}$ & $\mathrm{x}$ & $\mathrm{x}$ & & $\mathrm{x}$ \\
\hline roof material & $\mathrm{x}$ & & & & $\mathrm{x}$ & $\mathrm{x}$ & $\mathrm{x}$ & $\mathrm{x}$ & $\mathrm{x}$ & $\mathrm{x}$ & $\mathrm{x}$ & & $\mathrm{x}$ & $\mathrm{x}$ \\
\hline toilet & $\mathrm{x}$ & & $\mathrm{x}$ & $\mathrm{x}$ & & $\mathrm{x}$ & $\mathrm{x}$ & $\mathrm{x}$ & $\mathrm{x}$ & $\mathrm{x}$ & $\mathrm{x}$ & $\mathrm{x}$ & $\mathrm{x}$ & $\mathrm{x}$ \\
\hline tv set & & $\mathrm{x}$ & $\mathrm{x}$ & $\mathrm{x}$ & $\mathrm{x}$ & & $\mathrm{x}$ & $\mathrm{x}$ & $\mathrm{x}$ & $\mathrm{x}$ & $\mathrm{x}$ & $\mathrm{x}$ & & $\mathrm{x}$ \\
\hline internet & $\mathrm{x}$ & $\mathrm{x}$ & & & $\mathrm{x}$ & $\mathrm{x}$ & $\mathrm{x}$ & $\mathrm{x}$ & $\mathrm{x}$ & $\mathrm{x}$ & $\mathrm{x}$ & $\mathrm{x}$ & $\mathrm{x}$ & $\mathrm{x}$ \\
\hline
\end{tabular}


Appendix 2. Codification of Assets and Housing Materials

\begin{tabular}{|c|c|c|}
\hline & Coded 1 & Coded 0 \\
\hline sewage & $\begin{array}{l}10=\text { "Connected to sewage } \\
\text { system or septic tank" } \\
11=\text { "Sewage system (public } \\
\text { sewage disposal)" } \\
12=\text { "Septic tank (private } \\
\text { sewage disposal)" }\end{array}$ & $\begin{array}{l}20=\text { "Not connected to sewage } \\
\text { disposal system" }\end{array}$ \\
\hline fuel for cooking & $\begin{array}{l}20=\text { "Electricity" } \\
30=\text { "Petroleum gas, } \\
\text { unspecified" } \\
31=\text { "Gas -- piped/utility" } \\
32=\text { ="Gas -- tanked or bottled" } \\
33=\text { = "Propane" } \\
35=\text { "Liquefied petroleum gas" } \\
40=\text { "Petroleum liquid" } \\
41=\text { "Oil, kerosene, and other } \\
\text { liquid fuels" } \\
42=\text { "Kerosene/paraffin" } \\
43=\text { "Kerosene or oil" } \\
44=\text { "Kerosene or gasoline" } \\
45=\text { "Gasoline" } \\
46=\text { "Cocinol" } \\
60=\text { "Multiple fuels" } \\
61=\text { "Bottled gas and wood" } \\
62=\text { "Propane and electricity" } \\
63=\text { "Propane, kerosene, and } \\
\text { electricity" } \\
64=\text { "Propane and kerosene" } \\
65=\text { "Kerosene and electrictiy" } \\
66=\text { "Other combinations" }\end{array}$ & $\begin{array}{l}10=\text { "None" } \\
50=\text { "Wood, coal, and other } \\
\text { solid fuels" } \\
51 \text { = "Wood and other plant } \\
\text { fuels" } \\
52 \text { = "Non-wood plant } \\
\text { materials" } \\
53 \text { = "Coal or charcoal" } \\
54=\text { "Charcoal" } \\
55=\text { "Coal" } \\
56 \text { = "Wood or charcoal" } \\
70=\text { "Other" } \\
71=\text { "Alcohol" } \\
72=\text { "Biogas" } \\
73=\text { "Discarded or waste } \\
\text { material" } \\
74=\text { "Dung/manure" } \\
75=\text { "Dung or grass" } \\
76 \text { = "Solar energy" }\end{array}$ \\
\hline fuel for heating & $\begin{array}{l}02 \text { = "Electricity" } \\
03 \text { = "Fuel oil, kerosene, other } \\
\text { liquid fuels" } \\
04=\text { "Kerosene/paraffin" } \\
05=\text { "Diesel" } \\
06 \text { = "Gas" } \\
07 \text { = "Bottled gas, in tank, } \\
\text { liquified" }\end{array}$ & $\begin{array}{l}01=\text { "None" } \\
08=\text { "Solid fuel" } \\
09=\text { "Coal" } \\
10=\text { "Wood" } \\
11=\text { "Wood or coal" } \\
12=\text { "Solar" } \\
13=\text { "Animal dung" } \\
15=\text { "Other" } \\
16=\text { "Multiple sources" }\end{array}$ \\
\hline refrigerator & $2=$ "Yes" & $1=$ = No" \\
\hline $\begin{array}{l}\text { automobiles } \\
\text { available }\end{array}$ & $\begin{array}{l}1=\text { " } 1 \text { auto" } \\
2=\text { "2 autos" } \\
3=\text { "3 autos" } \\
4=\text { "4 autos" } \\
5=\text { = } 5 \text { autos" }\end{array}$ & $0=$ "No autos" \\
\hline
\end{tabular}




\begin{tabular}{|c|c|c|}
\hline & $\begin{array}{l}6=\text { " } 6+\text { autos" } \\
7=\text { "Have auto, number } \\
\text { unspecified" }\end{array}$ & \\
\hline computer & $2=$ "Yes" & $1=$ "No" \\
\hline $\begin{array}{l}\text { cellular phone } \\
\text { available }\end{array}$ & 1 = "Yes" & $2=$ "No" \\
\hline floor material & 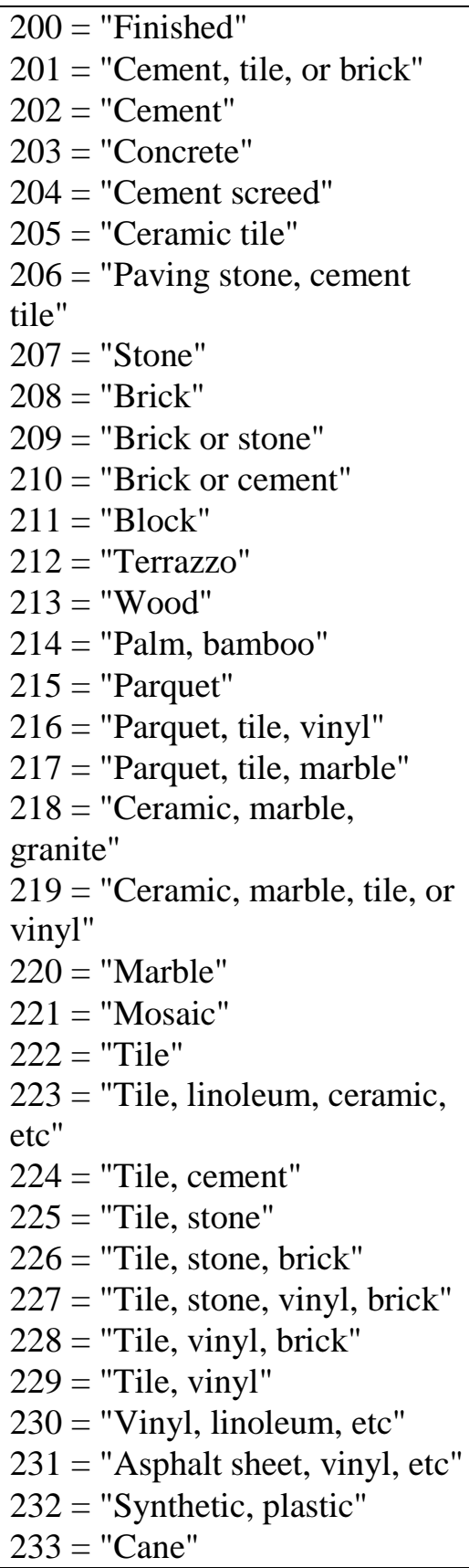 & $\begin{array}{l}100=\text { "None/unfinished (earth)" } \\
110=\text { "Sand" } \\
120=\text { "Dung" }\end{array}$ \\
\hline electricity & $1=$ "Yes" & $2=$ "No" \\
\hline \multirow[t]{3}{*}{$\begin{array}{l}\text { wall or building } \\
\text { material }\end{array}$} & $\begin{array}{l}500=\text { "Masonry, stone, cement, } \\
\text { adobe, metal, glass, and other } \\
\text { fabricated materials (sometimes } \\
\text { mixed with wood)" }\end{array}$ & 100 = "No walls" \\
\hline & $\begin{array}{l}501=\text { "Brick, block, stone, or } \\
\text { cement" }\end{array}$ & \multirow{2}{*}{$\begin{array}{l}200=\text { "Cardboard, scrap, and } \\
\text { miscellaneous materials" } \\
201=\text { "Waste, scrap, or } \\
\text { discarded material" }\end{array}$} \\
\hline & 502 = "Brick, stone, concrete" & \\
\hline
\end{tabular}


$503=$ "Brick, stone, or substitutes (dividing panels made of reinforced concrete)" $504=$ "Brick, stone, or substitutes (dividing panels made of wood)"

$505=$ "Brick or tile"

$506=$ "Brick or stone"

507 = "Brick or cement block"

$508=$ "Brick with plaster

exterior"

$509=$ "Brick without plaster exterior"

$510=$ "Burnt or stabilized brick"

511 = "Brick"

$512=$ "Unburnt brick"

$513=$ "Unburnt brick with cement"

514 = "Unburnt brick with mud"

$515=$ "Concrete"

$516=$ "Landcrete"

$517=$ "Cement blocks"

$518=$ "Cement blocks or brick"

$519=$ "Cement blocks or brick, unfinished"

$520=$ "Cement and adobe bricks"

$521=$ "Cement and stone block"

522 = "Reinforced concrete, precast concrete panels, or steel skeleton framed concrete" $523=$ "Concrete, reinforced concrete, blocks, panels"
$202=$ "Fabric or discarded material"

203 = "Zinc, fabric, cardboard, tins, and waste material"

$204=$ "Cardboard sheet"

205 = "Plastic sheeting, cardboard"

206 = "Makeshift, salvaged, or improvised materials"

207 = "Reused materials"

$300=$ "Wood"

$310=$ "Rough wood"

$320=$ "Wood or fibercement"

$330=$ "Wood, formica, and

other"

$340=$ "Wood or bamboo"

$350=$ "Wood or straw"

$400=$ "Other plant-based

materials"

$401=$ "Plantain leaves and

similar material"

402 = "Bamboo or cane"

403 = "Bamboo, sawali, cogon, nipa"

404 = "Straw or bamboo"

405 = "Grass, straw or reed"

406 = "Reed, bamboo, or palm"

524 = "Adobe"

$525=$ "Adobe walls with plaster exterior"

$526=$ "Adobe walls without plaster exterior"

$527=$ "Adobe with cement exterior"

$528=$ "Adobe (tabique,

quinche)"

$529=$ "Wood and earth adobe"

$530=$ "Wood and cement

adobe"

$531=$ "Mud or adobe"

$532=$ "Pressed dirt (similar to

adobe)"

533 = "Clay"

$534=$ "Coated clay/mud with

sticks/cane" 
$535=$ "Clay or clay-covered sticks"

$536=$ "Netted bamboo or cane with mud"

537 = "Bundle of mud, straw, other materials"

$538=$ "Mud with wood/wattle"

$539=$ "Pole and mud"

$540=$ "Mud with cement"

$541=$ "Unfinished lathe and

plaster, stucco, etc."

$542=$ "Stone"

543 = "Hand-laid stone"

544 = "Quarried stone"

$545=$ "Cut stone and concrete"

$546=$ "Cemented stone"

$547=$ "Stone with clay"

$548=$ "Blocks of light material"

549 = "Prefabricated material"

$550=$ "Asbestos"

$551=$ "Metal or asbestos sheet"

$552=$ "Metal or iron sheet"

553 = "Metal or fibercement

sheeting"

$554=$ "Galvanized iron or

aluminum"

$555=$ "Tin"

$556=$ "Glass"

$557=$ "Cloth"

$558=$ "Covintec panels"

559 = "Mixed material"

$560=$ "Mixed material: part

wood; part concrete, brick, or

stone"

$561=$ "Wood plastered with

clay, adobe, other materials;

wood pressed panels; rolled mud

bricks; etc."

$570=$ "Mainly permanent

telephone availability

water
$10=$ "Yes, piped water"

$11=$ "Piped inside dwelling"

$12=$ "Piped, exclusively to this

household"

$13=$ "Piped, shared with other

households"

$14=$ "Piped outside the

dwelling"

$15=$ "Piped outside dwelling, in

building"

$16=$ "Piped within the building

or plot of land" materials"

$1=$ "No"

$20=$ "No piped water" 
$17=$ "Piped outside the building

or lot"

$18=$ "Have access to public

piped water"

$10=$ "Masonry, concrete, clay

roof material

$11=$ "Concrete or cement"
$12=$ "Reinforced concrete
$($ slab)"
$13=$ "Cement or sheet metal"
$14=$ "Tile, unspecified"
$15=$ "Clay tile"
$16=$ "Tile or cement"
$17=$ "Modern tiles, industrial"
$18=$ "Traditional tiles, locally
made"
$19=$ "Tile or flat stone"
$20=$ "Fibercement or plastic"
$21=$ "Asphalt or laminate
cover"
$22=$ "Tile, cement, asphalt"
$23=$ "Asphalt tile"
$24=$ "Slate or tile"
$25=$ "Slate or asbestos"
$26=$ "Asbestos"
$27=$ "Adobe"
$28=$ "Tiles or wood planks"
$30=$ "Metal"
$31=$ "Sheet metal"
$32=$ "Zinc or tin"
$33=$ "Tin"
$34=$ "Sheet metal or other sheet
material"
$35=$ "Sheet metal, tile, slate"
$20=$ "Have toilet, type not
specified"
$21=$ "Flush toilet"

television set
20 = "Yes, color or black-and-

white not specified"

$21=$ "1 television"

$22=$ "2 televisions"

$23=$ " 3 televisions"

$24=$ "4 televisions"

$25=$ "5 televisions"

$26=$ "6 televisions"

$27=$ "7 televisions"
$40=$ "Wood and other plant

materials"

41 = "Wood"

42 = "Wood, including bamboo"

43 = "Bamboo"

$44=$ "Cogon, nipa, anahaw"

$45=$ "Thatch (straw, grass,

leaves, palm, etc.)"

46 = "Cane, wood, straw"

$47=$ "Grass"

$48=$ "Papyrus"

49 = "Banana leaves or fiber"

$50=$ "Palm or makuti"

$51=$ "Plant material with clay"

$52=$ "Grass and mud"

53 = "Straw, bamboo,

polythene"

$60=$ "Mud or earth"

$61=$ "Clay"

$70=$ "Cardboard, scrap, and

miscellaneous materials"

71 = "Discarded or scrap

material"

$72=$ "Cardboard"

$73=$ "Plastic"

$80=$ "Other, unspecified"

$10=$ "No toilet"

$11=$ "No flush toilet"

22 = "Non-flush, latrine"

23 = "Non-flush, other and

unspecified"

$10=$ "No" 


\begin{tabular}{|c|c|c|}
\hline & $\begin{array}{l}28=\text { " } 8 \text { televisions" } \\
29=\text { "9+ televisions" } \\
30=\text { "Yes, color only" } \\
31=\text { = } 1 \text { color tv" } \\
32=\text { " } 2 \text { color tvs" } \\
33=\text { = } 3+\text { color tvs" } \\
40=\text { "Yes, black-and-white } \\
\text { only" } \\
41=\text { = } 1 \text { black-white tv" } \\
42=\text { = } 2 \text { black-white tvs" } \\
43=\text { " } 3+\text { black-white tvs" } \\
50=\text { "Yes, both color and black- } \\
\text { and-white" } \\
52=\text { " } 2+\text { color and black-white } \\
\text { tvs" } \\
53=\text { = } 3+\text { color and black-white } \\
\text { tvs" } \\
54=\text { " } 4+\text { color and black-white } \\
\text { tvs" }\end{array}$ & \\
\hline \multirow[t]{3}{*}{ central heating } & $\begin{array}{l}2=\text { "Central heating, not } \\
\text { specified" }\end{array}$ & 1 = "No heating" \\
\hline & 3 = "Collective central heating" & $\begin{array}{l}6=\text { "No central heating/heating } \\
\text { unknown" }\end{array}$ \\
\hline & $\begin{array}{l}4=\text { "Individual central heating" } \\
5=\text { "Other heating, not central" }\end{array}$ & \\
\hline radio & $2=$ "Yes" & $1=$ "No" \\
\hline washer & $\begin{array}{l}2=\text { "Yes" } \\
3=\text { "Automatic of semi- } \\
\text { automatic" } \\
4=\text { "Wringer or other non- } \\
\text { automatic" }\end{array}$ & $1=$ "No" \\
\hline internet & 2 = "Yes" & $1=$ "No" \\
\hline
\end{tabular}

